JPdK Volume 2 No1 Tahun 2020 Halaman 126-129 JURNAL PENDIDIKAN dan KONSELING

\title{
Pengaruh Lingkungan Keluarga Terhadap Kepribadian Anak
}

\author{
Galih Mairefa Framanta \\ Program Studi Pendidikan Guru Sekolah Dasar \\ Falkutas Keguruan dan Ilmu Pendidikan \\ Universitas Kristen Satya Wacana \\ Email: galihframanta24@gmail.com
}

\begin{abstract}
Abstrak
Keluarga merupakan suatu lembaga pendidikan yang pertama dan utama, yang sangat menentukan akan masa depan suatu kehidupan keluarga. Merupakan suatu wadah dan tempat untuk tumbuh dan berkembangnya anak-anak (keluarga) secara keseluruhan. Dengan demikian keluarga berarti mempunyai peranan yang sangat besar dalam membentuk jiwa dan kepribadian seorang anak, karena baik buruknya pribadi dan jiwa anak sangat tergantung dari keluarga atau kedua orang tuanya. Kepribadian merupakan suatu sifat yang menjadikannya sebagai ciri tersendiri dari orang lain yang tercerminkan dari tingkah laku, cara berbicara, cara berfikir.
\end{abstract}

Kata Kunci : Orang Tua, Kepribadian Anak

\section{PENDAHULUAN}

Keluarga merupakan suatu lembaga pendidikan yang pertama dan utama, yang sangat menentukan akan masa depan suatu kehidupan keluarga. Merupakan suatu wadah dan tempat untuk tumbuh dan berkembangnya anak-anak (keluarga) secara keseluruhan. Dengan demikian keluarga berarti mempunyai peranan yang sangat besar dalam membentuk jiwa dan kepribadian seorang anak, karena baik buruknya pribadi dan jiwa anak sangat tergantung dari keluarga atau kedua orang tuanya.

Pembentukan kebiasaan adalah penanaman atau latihan-latihan terhadap kecakapan-kecakapan berbuat, mengucapkan sesuatu atau mengerjakan sesuatu, seperti cara berpakaian, bangun pagi, cara beribadah, dan sebagainya. Karena pembiasaan dan latihan tersebut akan membentuk sikap tertentu pada anak, yang lambat laun sikap itu akan bertambah dan semakin kuat, akhirnya sudah menjadi pedoman karena telah masuk menjadi bagian dari pribadinya. Anak prasekolah biasanya akan meniru apa yang di ajarkan oleh orang tua, baik secara langsung maupun tidak langsung. Sehingga orang tua harus mampu meningkatkan pengetahuan dan kemampuan dalam menciptakan lingkungan dan kondisi keluarga yang kondusif untuk menunjang proses perkembangan anak.

Danziger (1976:62-63) mengatakan bahwa ada dua fungsi pokok dalam proses interaksi orang tua - anak, yaitu fungsi tuntutan (demand) dan dukungan (support). Tuntutan merupakan harapan untuk melakukan atau tidak melakukan suatu perbuatan dan dukungan merupakan respon positif terhadap terpenuhinya harapan. Tuntutan dapat bersifat positif dan negatif. Bersifat positif apabila tuntutan itu akan memberi dorongan, menstimulasi, mengontrol perilaku anak, dan bersifat negatif bilamana tuntutan tersebut membatasi ruang gerak anak. Menurut Piaget ada empat tahap perkembangan mental, yaitu: (1) Tahap sensori motor. Pada tahap ini anak dalam memahami lingkungan melalui reflekreflek motorik dan pengindraan serta sudah mencapai kemampuan dalam mempersepsikan ketetapan obyek. Oleh karena itu, dalam memberi tuntutan akan lebih efektif disampaikan melalui sentuhan, gerakan. Sebagai contoh untuk menyuruh anak 
tidur, dapat dilakukan dengan mengayun, mendongeng, dll. Begitu pula sebaliknya,dalam menanggapi tuntutan anak dapat dipahami dari gerakan atau isyarat anak, misalnya tangisan dan senyuman. (2) Tahap pra operasional. Pada tahap ini anak sudah dapat menggunakan simbol atau bahasa dan menggunakan tanggapan internal peniruan. Tanggapan yang diberikan masih berorientasi pada egonya. Oleh karena itu, penyampaian tuntutan dapat disampaikan dengan bahasa yang sederhana dan nyata. nalam menanggapi tuntutan anak dapat dilakukan dengan mendasarkan pada ego anak. (3) Tahap operasional konkret. Anak sudah memiliki kemampuan berpikir sistematis terhadap obyek konkret. Hal ini memungkinkan orang tua dalam memberi tuntutan, menggunakan penjelasan terhadap situasi nyata yang dihadapi anak, dengan bukti atau contoh yang konkret. (4) Tahap operasional formal. Pada tahap ini anak sudah mencapai kemampuan berpikir sistematis terhadap hal-hal yang abstrak. Dalam memberi tuntutan pada anak, perlu diberi alasan, penjelasan secara rasional, sebab anak tidak akan menerima atau mendukung begitu saja terhadap setiap tuntutan yang ada. Anak akan menanyakan sebab-sebabnya, keuntungan kerugiannya terhadap setiap tuntutan, mengapa suatu tindakan perlu atau tidak perlu dilakukan.Sebagaimana telah dikemukakan di muka bahwa pengaruh orang tua terhadap perkembangan kepribadian anak tergantung dua faktor, yaitu tuntutan orang tua terhadap anak dan keberhasilan orang tua di dalam memuaskan tuntutan anak.

Menurut teori psikologi, dikemukakan oleh Fillmore H.Sandfprd, bahwa kepribadian adalah sesuatu yang unik dari sifat-sifat seseorang yang berlangsung lama. Dapat diambil kesimpulan bahwa kepribadian merupakan suatu sifat yang menjadikannya sebagai ciri tersendiri dari orang lain yang tercerminkan dari tingkah laku, cara berbicara, cara berfikir, dan lain-lain. Kepribadian juga dapat disebut dengan watak atau karakter untuk menciptakan kepribadian seseorang.

\section{METODOLOGI PENELITIAN}

Metode penelitian yang digunakan ini adalah studi pustaka yang merupakan langkah awal dalam metode pengumpulan data. Menurut Sugiyono, 2005:83 Studi pustaka merupakan metode pengumpulan data yang diarahkan kepada pencarian data dan informasi melalui dokumen-dokumen, baik dokumen tertulis, foto-foto, gambar, maupun dokumen elektronik yang dapat mendukung dalam proses penulisan. Penelitian studi pustaka ini melibatkan beberapa hasil penelitian yang didapatkan melalui penulisan Google Scholar, dan Google Cendekia. Dari hasil penulusuran yang didapatkan 4 artikel yang relevan. Dasar dari pengambilan artikel tersebut adalah adanya landasan teori yang dapat dijadikan pedoman ketika melakukan pemecahan masalah pada hipotesis.

\section{HASIL PENELITIAN DAN PEMBAHASAN}

Di dalam lingkungan suatu keluarga dimana anak-anak berinteraksi baik dengan ke dua orang tuanya beserta segenap anggota keluarga lainnya, maka mereka dengan sendirinya akan dengan mudah memperoleh sentuhan pendidikan formal berupa pembentukan pembiasaan-pembiasaan seperti cara makan, tidur, bangun pagi, berpakaian, sopan santun dan sebagainya. Demikian pula halnya dengan pendidikan informal di dalam keluarga akan banyak membantu dalam meletakkan dasar- dasar pembentukan kepribadian anak.

Kemudian kategori aspek kepribadian seseorang pada garis besarnya dapat digolongkan ke dalam tiga hal, yaitu sebagai berikut:

1. Aspek-aspek kejasmanian, yang meliputi tingkah laku luar yang mudah nampak dan ketahuan dari luar, misalnya cara- caranya berbuat dan berbicara.

2. Aspek-aspek kejiwaan, meliputi yang tidak segera dapat diihat dan ketahuan dari luar, misalnya cara-cara seseorang berfikir, bersikap dan minatnya.

3. Aspek-aspek kerohanian yang luhur, meliputi aspek-aspek kejiwaan yang lebih abstrak, yaitu falsafah hidup dan kepercayaan. Ini meliputi sistem nilai yang telah meresap ke dalam kepribadian, yang telah menjadi bagian dan mendarah daging 
dalam kepribadian seseorang yang dapat mengarahkan dan memberi corak seluruh kehidupan individu.

Upaya membentuk kepribadian anak yaitu tindakan dan perlakuan kedua orang tua terhadap anak-anak dan saudara-saudaranya merupakan perilaku yang akan menjadi bagian dari kepribadian keluarganya di kemudian hari. Tindakan dan perlakuan orang tua yang sesuai dengan ajaran ajaran agama dan norma susila, akan menimbulkan pengalaman-pengalaman hidup dalam jiwa anak yang sesuai dengan agama, yang kemudian akan tumbuh dan menjadi unsur-unsur yang merupakan bagian dalam pribadinya nanti.

Faktor yang mempengaruhi kepribadian yaitu :

a. Faktor Genetik merupakan bawaan anak dari orang tuanya. Pengaruh ini bisa bermacam-macam yang merupakan sifat dasar bawaan, seperti contoh pemarah, penyabar, santun, nakal, keras kepala, kuat kemauan, dan lain sebagainya yang sangat berpengaruh cepat atau lambatnya pembentukan kepribadian seseorang.

b. Faktor Keluarga pengaruh dalam membentuk kepribadian sangatlah besar dan ada beberapa ranah yang terdiri dari fase embrio, fase bayi, fase anak, dan fase dewasa

c. Faktor Lingkungan yaitu lingkungan sekitar yang terdiri dari teman bermain, tetangga, dan juga lingkungan pendidikan. Lingkungan pendidikan ini adaada yang langsung memberi warna dan pengaruh yang kental ada juga yang sekedar menyajikan disiplin ilmu tertentu.

Anak dapat belajar kepribadian dengan efektif melalui:

1. Setiap anak akan belajar kepribadian terbaik pada situasi kongkrit yang melibatkan kegiatan fisik atau aktif dan kesepakatan untuk menemukan faktor-faktor sendiri.

2. Daya serap akan meningkat jika konsep disajikan dalam konteks yang akrab dengan anak.

3. Anak belajar kepribadian lebih baik jika diberikan contoh yang konkrit, ada tantangan, dapat dirasakan oleh indera dan pengalaman langsung.
4. Kebanyakan anak belajar lebih baik melalui interaksi dengan anak atau guru maupun orang tua.

5. Belajar dengan menghafal konsep-konsep kepribadian merupakan strategi belajar yang relatif dan efisien untuk anak-anak.

1. Otak tidak dibentuk saat bayi didalam rahim, tapi dibentuk oleh pengalaman dan belajar. Pengalam itu adalah kuncinya.

2. Mengajarkan atau menanamkan kepribadian atau memberikan pengaruh pada kerja otak, maka kita harus mengadaptasi teknik mengajar atau menanamkan kepribadian sesuai dengan riset otak.

Agar pengenalan, penanaman, dan pembiasaan kepribadian lebih konekstual kepada anak, maka beberapa faktor yang harus dipertimbangkan

a. Relating yaitu belajar dalam konteks pengalaman hidup yaitu menggunakan hal-hal yang familiar dalam kehidupan anak kemudian dihubungkan dengan informasi yang ada didalam pengalaman.

b. Exsperiencing yaitu belajar dalam konteks eksplorasi. Anak akan lebih cepat belajar kepribadian jika anak-anak terlibat dan dapat mengengsplorasi langsung benda yang disebut.

c. Applying yaitu aplikasi konsep dan informasi dalam konteks yang bermakna, seperti praktek langsung menirukan apa yang sudah diajarkan.

d. Cooperating yaitu memberikan tanggapan dan berkomunikasi dengan anak yang lainnya. Belajar bersama tidak hanya memberikan kesempatan anak belajar konsep tetapi juga fokus pada dunia nyata. e. Transfering yaitu belajar untuk menggunakan informasi atau keterampilan yang dibangun dalam situasi yang berbeda. Anak mampu menerapkan keterampilan menyelesaikan masalahnya ketika berhadapan langsung dengan sesuatu yang baru.

Dalam pembentukan pribadi anak pembiasaan dan latihan sangat penting, karena pembiasaan dan latihan itu akan memasukkan unsur-unsur positif dalam pribadi anak yang sedang tumbuh. Semakin banyak pengalaman dan latihan yang diperolehnya melalui pembiasaan itu, maka semakin banyaklah pengalaman di dalam pribadinya dan semakin mudahlah ia 
dibentuk dengan nilai yang positif. Pembentukan pengertian dan sikap pada taraf pertama baru merupakan drill, dengan tujuan agar caranya dilakukan lebih tepat, kemudian pada taraf kedua barulah diberi pengertian dan pengetahuan.

\section{SIMPULAN}

Keluarga merupakan suatu lembaga pendidikan yang pertama dan utama, yang sangat menentukan akan masa depan suatu kehidupan keluarga. Merupakan suatu wadah dan tempat untuk tumbuh dan berkembangnya anak-anak (keluarga) secara keseluruhan. Dengan demikian keluarga berarti mempunyai peranan yang sangat besar dalam membentuk jiwa dan kepribadian seorang anak, karena baik buruknya pribadi dan jiwa anak sangat tergantung dari keluarga atau kedua orang tuanya.

Kepribadian merupakan suatu sifat yang menjadikannya sebagai ciri tersendiri dari orang lain yang tercerminkan dari tingkah laku, cara berbicara, cara berfikir, dan lain-lain. Kepribadian juga dapat disebut dengan watak atau karakter untuk menciptakan kepribadian seseorang. Dalam pembentukan pribadi anak pembiasaan dan latihan sangat penting, karena pembiasaan dan latihan itu akan memasukkan unsur-unsur positif dalam pribadi anak yang sedang tumbuh. Semakin banyak pengalaman dan latihan yang diperolehnya melalui pembiasaan itu.

\section{DAFTAR PUSTAKA}

Sugito. INTERAKSI DALAM

KELUARGA SEBAGAI DASAR PENGEMBANGAN

KEPRIBADIAN ANAK. Jurnal Ilmiah Pendidikan.

Saputro, Heri danYufentri Otnial Talan, 2017. Pengaruh Lingkungan Keluarga Terhadap Perkembangan Psikososial Pada Anak Prasekolah. Journal Of Nursing Practice, 1(1), 1-8.

Sukaimi, Syafi'ah. 2013. PERAN ORANG TUA DALAM PEMBENTUKAN KEPRIBADIAN ANAK: TINJAUAN PUSTAKA 